\title{
Old colchicine-induced polyploid materials of Betula pendula Roth and Betula pubescens Ehrh.
}

\author{
K. Pieninkeroinen and T. Valanne
}

Department of Biology. University of Turku, SF-20500 Turku, Finland

\section{Introduction}

The members of the genus Betula form a particularly significant group of broadleaved trees in Eurasia and North America. Certain birch species, e.g., B. pendula, $B$. pubescens and $B$. papyrifera, are valuable sources of wood and great importance is attached to breeding work aimed at their economic improvement.

Polyploidy indiced by colchicine treatment in B. pendula and B. pubescens has been ieported by Johnsson and Eklundh (1940), Schröck (1951) and Valanne (1972). The rate of growth of induced Betula polyploids has been observed to be inferior to that of the diploid parental trees (Johnsson, 1956; Eifler, 1955; 1967). It has also been reported that triploid $B$. pendula trees obtained from cross-pollination of colchicine tetraploid and diploid trees did not grow faster than the diploid control plants (Johnsson, 1956). The aim of this study was to reveal possible breeding and evolutionary trends in $B$. pendula and $B$. pubescens.

\section{Materials and Methods}

The material was part of about 2000 individually numbered ca $25 \mathrm{yr}$ old $B$. pendula and $B$. pubescens trees, which originated from extensive colchicine experiments with different birch species carried out in Finland (Valanne, 1972). The birches from the experiments are located on the island of Seili $\left(60^{\circ} 12^{\prime} N, 21^{\circ} 55^{\prime} \mathrm{E}\right)$, at the Experimental Station of the Finnish Forest Research Institute, Punkaharju $\left(61^{\circ} 43^{\prime} \mathrm{N}\right.$, $\left.29^{\circ} 25^{\prime} \mathrm{E}\right)$, at Päilahti by Orivesi $\left(61^{\circ} 37^{\prime} \mathrm{N}\right.$, $\left.24^{\circ} 29^{\prime} \mathrm{E}\right)$ and in the Botanical Garden of the University of Turku, Ruissalo $\left(60^{\circ} 26^{\prime} \mathrm{N}, 22^{\circ} 10^{\prime}\right.$ E). From the materials of Punkaharju, Orivesi and Turku, 50 B. pendula and 50 B. pubescens trees were taken for this study.

The chromosome counts were carried out according to the method of Hömmö and Särkilahti (1986), using young leaves. Arnott's (1959) method of clearing leaves was used to study stomata. For the measurement of wood fibres and vessels, wood tissue was macerated according to the method for broad-leaved trees.

\section{Results}

The retarding effect of colchicine on the height growth of birches is strong. In the colchicine-induced polyploids, both the height and the diameter (dbh) were significantly smaller than in the colchicine-treated chromosomally normal trees (Table I). Some diploid $B$. pendula trees reached a height of nearly $20 \mathrm{~m}$, while the highest polyploids were under $14 \mathrm{~m}$. The colchi- 
Table I. The mean ( \pm SE) height and dbh in chromosomally normal and colchicine-polyploid trees of $B$. pendula and $B$. pubescens.

\begin{tabular}{lrrrrr}
\hline & $n$ & Height $(\mathrm{m})$ & $\mathrm{F}$ & $\mathrm{dbh}(\mathrm{cm})$ & $\mathrm{F}$ \\
\hline B. pendula & & & & & \\
$2 x=28$ & 24 & $15.5 \pm 1.0$ & & $20.2 \pm 1.3$ & \\
$4 x=56$ & 26 & $8.1 \pm 0.6$ & $41.3^{\star \star \star}$ & $11.5 \pm 0.9$ & $32.1^{\star \star \star}$ \\
B. pubescens & & & & \\
$4 x=56$ & 7 & $15.2 \pm 0.3$ & & $19.9 \pm 0.6$ & \\
$6 x, 7 x, 8 x$ & 43 & $7.4 \pm 0.3$ & $97.6^{\star \star \star}$ & $10.1 \pm 0.6$ & $39.7^{\star \star}$ \\
\hline
\end{tabular}

Differences tested with analysis of variance, significance: ${ }^{\star \star} P<0.001,{ }^{\star *} P<0.01$.

Table II. The mean ( $\pm \mathrm{SE}$ ) length of guard cells of stomata, wood fibres and vessels of chromosomally normal and colchicine-polyploid trees of $B$. pendula and $B$. pubescens.

\begin{tabular}{llll}
\hline & $\begin{array}{l}\text { Stomata } \\
(\mu \mathrm{m})\end{array}$ & $\begin{array}{l}\text { Wood fibres } \\
(\mu \mathrm{m})\end{array}$ & $\begin{array}{l}\text { Wood vessels } \\
(\mu \mathrm{m})\end{array}$ \\
\hline $\begin{array}{l}\text { B. pendula } \\
2 x=28\end{array}$ & $31.7 \pm 0.2$ & & \\
$4 x=56$ & $44.2 \pm 0.3^{\star \star \star}$ & $664.6 \pm 5.6$ & $458.0 \pm 4.5$ \\
B. pubescens & & $892.0 \pm 4.0^{\star \star \star}$ & $635.2 \pm 3.3^{\star \star \star}$ \\
$4 x=56$ & $37.6 \pm 0.3$ & $687.9 \pm 10.6$ & $467.9 \pm 6.7$ \\
$6 x, 7 x, 8 x$ & $54.0 \pm 0.2^{\star \star \star}$ & $924.6 \pm 3.6^{\star \star \star}$ & $687.4 \pm 2.8^{\star \star \star}$ \\
\hline
\end{tabular}

Differences tested with analysis of variance, significance: $* \star \star ~ P<0.001$.

cine treatment caused branching. No statistically significant difference was found in branch numbers between the groups.

The petioles of polyploid $B$. pendula trees were thicker than those of diploid ones, containing more parenchymatous and vascular tissue. In the tetraploids, the cell size of the parenchymatous tissue was greater in relation to other cell types than in the diploid trees. In the polyploid trees, the sclerenchymatous tissue around the vascular bundle seemed to be more abundant and its cells often had thinner walls than in the diploids.

The guard cells of the stomata were significantly longer in the induced polyploids than in the colchicine-treated chromosomally normal trees (Table II). The lengths of the guard cells of the normal trees were on an average $70 \%$ of those of the induced polyploids.
In the colchicine polyploids, the wood fibres and vessels were statistically significantly longer and the vessels wider than in the chromosomally normal trees (Table II). The mean lengths of the fibres and vessels of polyploid $B$. pendula were several tens of micrometres smaller than those of polyploid $B$. pubescens. In some $B$. pubescens trees with the longest wood fibres, the mean length exceeded $1 \mathrm{~mm}$. The shortest wood fibres were recorded in some diploid $B$. pendula trees, the mean value being under $0.6 \mathrm{~mm}$.

\section{Discussion and Conclusion}

Retardation of the height groswth is a typical effect of colchicine in the Betula species studied (Table 1). This has already 
been seen in the initial stages of saplings (Johnsson and Eklundh, 1940; Valanne, 1972). On the other hand, the cell size of colchicine polyploids is greater (Table II), and the leaves and leaf organs are greater than at the diploid level.

The chromosome number of a considerable part (33 trees) of the $B$. pubescens material is heptaploid with $7 x=98$, and only a small number of the trees have the expected $8 x=112$ (6 trees). The large proportion of heptaploid trees suggests that the chromosome set of $B$. pubescens consists of $42+14$ chromosomes $(3 x+x)$, and that in the colchicine treatments 42 chromosomes have been duplicated, while 14 chromosomes are unchanged. In our experiments with birches of the subsection Nanae (B. glandulosa and $B$. nana, both $2 n=28, x=14$ ), no colchicine polyploids have been obtained. In the literature, it has been suggested that the $B$. pubescens genome contains a genome of the subsection Nanae (e.g., Walters, 1968). The abundance of trees with $7 x=98$ occurring in our $B$. pubescens material supports this suggestion.

\section{References}

Arnott J. (1959) Leaf clearings. Turtox News 37, 192-194

Eifler I. (1955) Künstliche polyploidie-erzeugung bei Picea abies und Betula verrucosa. $Z$. Forstgen. Forstpflanzenzücht. 4, 162-166

Eifler I. (1967) Anwendungsmöglichkeiten der polyploidie-züchtung in der forstwirtschaft. Arch. Forstwes. 16, 515-528

Hömmö L. \& Särkilahti E. (1986) A method of counting chromosomes of hardwood trees using root tips and young leaves. Can. J. For. Res. 16, 401-403

Johnsson H. (1956) Auto- and allotriploid Betula families, derived from colchicine treatment. Z. Forstgen. Forstpflanzenzücht. 5, 65-70

Johnsson H. \& Eklundh C. (1940) Colchicinbehandling som metod vid växtföredling av lövträd. Sven. Papperstidn. 43, 355-360, 373-377

Schröck O. (1951) Stimulierende wirkung des colchicins bei der keimung und wachstum der sämlinge. Züechter, 21, 142-149

Valanne T. (1972) Colchicine effects and colchicine-induced polyploidy in Betula. Ann. Acad. Sci. Fenn. Ser. A4 Biol. 191, 1-28

Walters S.M. (1968) Betula in Britain. Proc. Bot. Soc. Br. IsI. 7, 179-180 